\title{
Measurement of Transient Horizontal Electric Fields Using Two Vertical Conducting Probes
}

\author{
Shuichi Asano Student Member (Doshisha University, dte0103@mail4.doshisha.ac.jp) \\ Yoshihiro Baba Member (Doshisha University, ybaba@mail.doshisha.ac.jp) \\ Nobutaka Mori Member (Doshisha University, nmori@mail.doshisha.ac.jp) \\ Naoto Nagaoka Member (Doshisha University, nnagaoka@mail.doshisha.ac.jp) \\ Akihiro Ametani Member (Doshisha University, aametani@mail.doshisha.ac.jp)
}

Keywords: FDTD method, lightning, horizontal electric field, ground conductivity

Vertical and horizontal electric fields associated with lightning are of importance because they are responsible for inducing voltages on overhead power distribution and telecommunication lines. In some circumferences, the horizontal electric field is more important than the vertical electric field in inducing voltages on those overhead lines even though the horizontal field is much smaller than the vertical field. There are only a few reports of measurements of the horizontal electric field associated with lightning. This fact indicates that it is difficult to measure the lightning-associated horizontal electric fields with a reasonable accuracy. In this paper, a simple system for measuring a transient horizontal electric field along the surface of lossy ground is tested.

Figure 1 shows the proposed system that is located near a vertical wire of length $4 \mathrm{~m}$ excited at its bottom by a pulse voltage generator in series with a $0.5-\mathrm{k} \Omega$ resistor. The proposed system comprises two vertical conducting probes of length $0.5 \mathrm{~m}$ driven into ground, two series resistors of $0.5 \mathrm{k} \Omega$ connecting the tops of the two vertical probes, and two voltage probes used for a differential mode. The separation between the two vertical probes is set to $d=0.25 \mathrm{~m}$. The ground conductivity, evaluated by Wenner's four-electrode method, is $\sigma=26.5 \mathrm{mS} / \mathrm{m}$. Transient horizontal electric field $E_{h}$ is evaluated as the voltage difference $V_{h}$ between the two vertical conducting probes $\left(E_{h}=V_{h} / d\right)$.

Figure 2 shows a waveform of horizontal electric field along the surface of ground of $\sigma=26.5 \mathrm{mS} / \mathrm{m}$ measured by the system

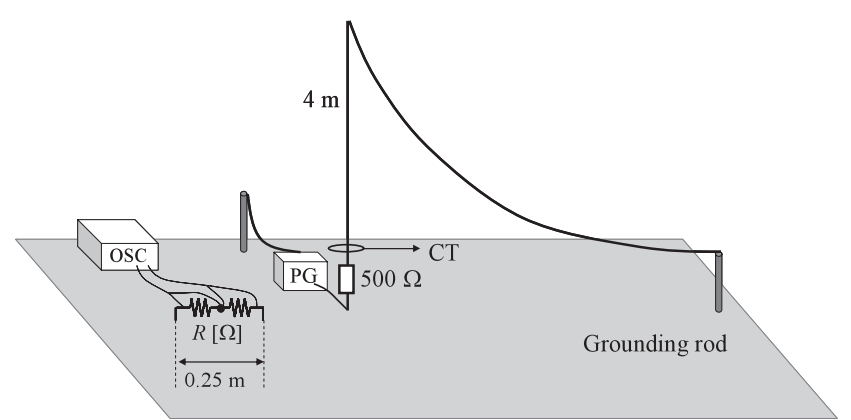

Fig. 1. Setup for the measurement of horizontal electric field along the surface of ground shown in Fig. 1, and that calculated by the finite-difference timedomain (FDTD) method for the same configuration. The measured waveform agrees well with the FDTD-calculated waveform. Figure 3 shows that an FDTD-calculated waveform of horizontal electric field calculated for the configuration in Fig. 1 in the presence of the simple system and that for the same configuration in its absence. The two waveforms agree well with each other. The agreement shows that horizontal electric fields can be measured by the system with a reasonable accuracy.

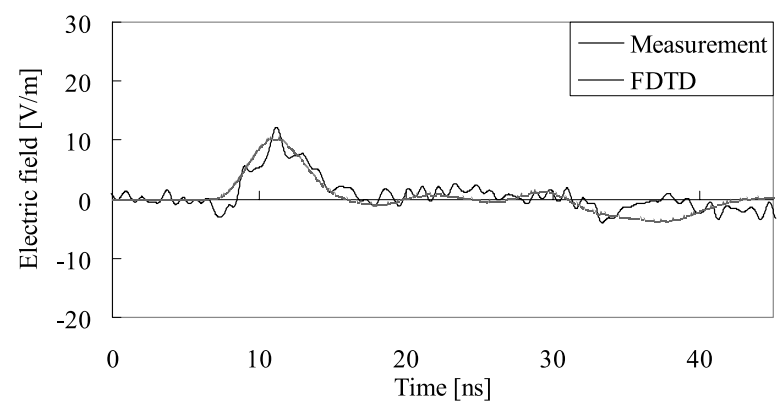

Fig. 2. Measured and FDTD-calculated waveforms of horizontal electric field for the configuration shown in Fig. 1

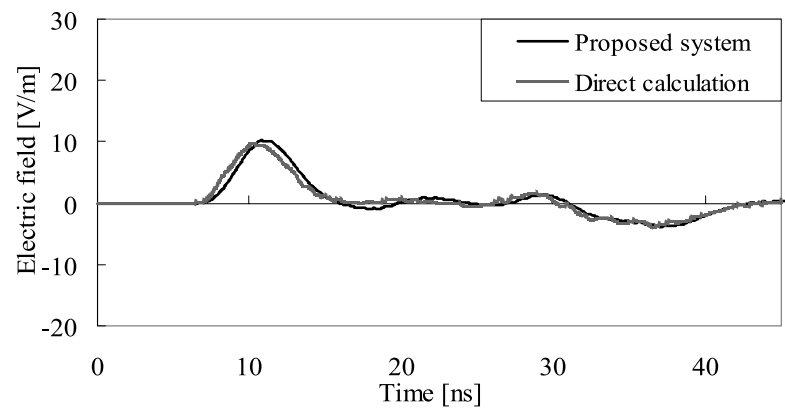

Fig. 3. FDTD-calculated waveforms of horizontal electric field for the configuration in Fig. 1 both in the presence of the measuring system and in its absence 


\section{2 垂直導体プローブによる過渡水平電界の測定}

$\begin{array}{lllll}\text { 学生員 浅野 } & \text { 修一* } & \text { 正 員 馬場 吉弘* } \\ \text { 正員 森 } & \text { 延孝* } & \text { 正 員 長岡 直人* } \\ \text { 正 員 雨谷 } & \text { 昭弘* } & & & \end{array}$

\section{Measurement of Transient Horizontal Electric Fields Using Two Vertical Conducting Probes}

Shuichi Asano*, Student Member, Yoshihiro Baba*, Member, Nobutaka Mori*, Member, Naoto Nagaoka*, Member, Akihiro Ametani*, Member

A simple system for the measurement of transient horizontal electric field along the surface of lossy ground is tested in this paper. The system comprises two vertical conducting probes driven into ground, two series resistors connecting the tops of the two vertical probes, and two voltage probes. Transient horizontal electric field is evaluated as the voltage difference between the tops of the two vertical conducting probes. FDTD simulations show that the transient horizontal electric field evaluated using the measuring system agrees well with that calculated directly in the absence of the system. Furthermore, transient horizontal electric field measured in a small-scale experiment is also in good agreement with the corresponding FDTD-calculated electric field.

キーワード : FDTD 法, 雷, 水平電界, 大地導電率

Keywords: FDTD method, lightning, horizontal electric field, ground conductivity

\section{1. 緒言}

帰還雷撃に伴って生じる大地面に垂直な電界の測定例 ${ }^{(1)}$ は多いが，大地面に水平な電界の測定例 (2) (5) は少ない。こ のことは水平電界測定の難しさを示していると考えられる。 一般に，電界の測定は，測定したい方向の電界に垂直に配 置した平らな電極の表面に誘導される電荷量が電界に比例 することを利用している。したがって，垂直電界を測定す るためには平板電極を水平に，水平電界を測定するために は平板電極を垂直に配置する必要がある。埽還雷撃によっ て地表面付近に生じる垂直電界の強さは水平電界のそれに 比べて数十倍程度大きいことから (2) (5), 水平電界測定用電 極の配置の狂い等により, 垂直電界成分が水平方向電界の 測定結果にノイズとして混入する。このノイズ成分をソフ トウエア的に除去する手法が確立されてはいるが(2) (5), 帰 還雷撃に起因した過渡水平電界の高精度な測定には，極め て高い技術が必要である。

本論文では，上述の測定法とは異なる原理に基づく一対 の埋設電極 (エルドアンテナ) (6)を用いた過渡水平電界の簡 易測定システムの動作特性について, 縮小モデル実験およ

\footnotetext{
* 同志社大学 工学部

干 610-0321 京田辺市多々羅都谷 1-3

Department of Electrical Engineering, Doshisha University

1-3, Miyakodani, Tatara, Kyotanabe 610-0321
}

びFDTD（Finite Difference Time Domain）法(7)を用いた シミュレーションを実施し検討を行う。本論文は 5 章から 構成される。2 章では, 簡易測定システムの基本原理につ いて説明を行う。3 章では, 縮小モデル実験を実施し, 同測 定システムにより測定した過渡水平電界波形を示す。 4 章 では，3章の縮小モデル実験を模擬したFDTD シミュレー ションを行い, 過渡水平電界の計算波形が測定波形と良好 に一致すること示す。

\section{2. 簡易測定システムの基本原理}

境界面に接する方向の電界は連続であることから, 地表 面よりやや上の気中の水平電界の強さと地表面よりやや下 の土中の水平電界の強さは, ほぼ等しいと考えられる。こ のことから, 図 1 に示すように, 垂直導体プローブ (棒) 2 本を $d[\mathrm{~m}]$ 離して大地に打ち込み, それらの頂部間の電位 差 $V_{h}[\mathrm{~V}]$ を電圧プローブで測定すれば，プローブの打ち込 み点を結ぶ方向の水平電界が $E_{h}=V_{h} / d[\mathrm{~V} / \mathrm{m}]$ として得ら れると考えられる。

なお, 電圧プローブへの誘導の影響を極力除去するため, 垂直導体プローブ間の電位差は以下に述べるように擬似差 動測定を行う。垂直導体プローブの頂部間に同一の高抵抗 2 つを直列に挿入し，2つの電圧プローブの接地側端子を 2 抵抗の接続点（中央）に接続し，他方の端子をそれぞれ垂 直導体プローブの頂部に接続する。そして, それぞれの電 


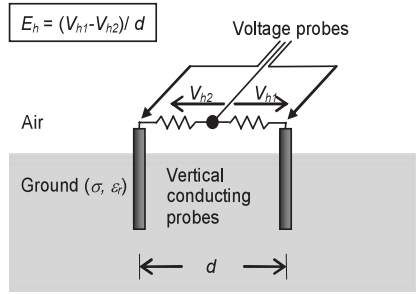

図 1 地表面に生じる水平電界の簡易測定システムの 原理

Fig. 1. Schematic diagram of a simple system for the measurement of horizontal electric field along the surface of lossy ground.

圧プローブによる測定電圧 $V_{h 1}[\mathrm{~V}], V_{h 2}[\mathrm{~V}]$ の差として垂 直導体プローブ間の電位差 $V_{h}=V_{h 1}-V_{h 2}[\mathrm{~V}]$ を評価する。

測定可能周波数带域は，種々の要素によって決まると考 えられるが，例えば垂直導体プローブの間隔を $0.3 \mathrm{~m}$ とす れば，原理的には波長が $3 \mathrm{~m}$ 以上（周波数約 $100 \mathrm{MHz}$ 以 下）程度の水平電界の測定が可能と考えられる。

\section{3. 縮小モデル実験}

〈3.1〉実験配置図 2 に実験配置を示す。半径 $0.5 \mathrm{~mm}$ の被覆銅線（全長約 $16 \mathrm{~m}$ ）を塩ビパイプで支持し 高さ $4 \mathrm{~m}$ まで垂直に張り，そこから緩やかに弛ませて $11 \mathrm{~m}$ 離れた地点に打ち込んだ接地電極に接続した。高さ $4 \mathrm{~m}$ の

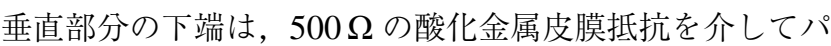
ルス電圧発生器（NoiseKen INS-4040）に接続した。被覆 銅線に流入する電流は, CT (Pearson 社製 2877 モデル) を 用いて測定した。帰還雷撃を模擬するという観点からは, 被覆銅線の垂直部分は長い方が望ましいが，過渡水平電界 の測定システムを試験するという目的においては，垂直部 分の長さは特に問題とはならない。

水平電界測定用の垂直導体プローブとしては, 半径 $6.5 \mathrm{~mm}$, 長さ $0.5 \mathrm{~m}$ の金属棒を採用した。金属棒の打ち込 み間隔は $0.25 \mathrm{~m}$ とし, 長さ約 $16 \mathrm{~m}$ の被覆銅線の水平部分と 逆側に配置した。被覆銅線の垂直部分から垂直導体プロー ブ中央部分までの距離は $D=1 ， 2 ， 3$ および $4 \mathrm{~m}$ とした。 垂直金属棒の頂部間には 2 つの酸化金属皮膜抵抗 $(0.5 \mathrm{k} \Omega$

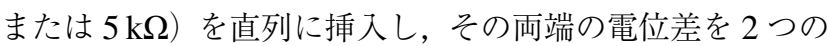
電圧プローブ（Tektronix 社製 P6139A 型）を用いて擬似差 動測定した。

実験は同志社大学京田辺校地内のグランドで行った。実 測日に (2005 年 10 月 18 日), このグランドの大地抵抗率を, Wenner の 4 電極法 (横河電機大地比抵抗測定器 324400 ) に より測定したところ, $\rho=37.7 \Omega \mathrm{m}$ (導電率 $\sigma=26.5 \mathrm{mS} / \mathrm{m}$ ) であった。

〈3.2〉 実験結果 パルス電圧発生器の出力端子間で 測定した電圧波形を図 3 に，このパルス電圧発生器から数 十 $\mathrm{cm}$ 離れた長さ $4 \mathrm{~m}$ の垂直被覆銅線の下端で測定した電 流波形を図 4 に示寸。図 4 の電流測定波形には，図 3 の印 加電圧波形（立ち上がり時間約 $4 \mathrm{~ns}$ ）には見られない周期

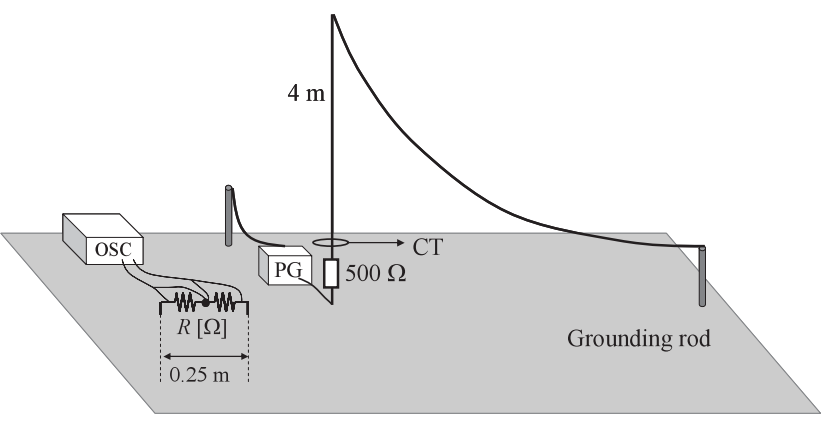

図 2 水平電界測定のための実験配置

Fig. 2. Setup for the measurement of horizontal electric field.

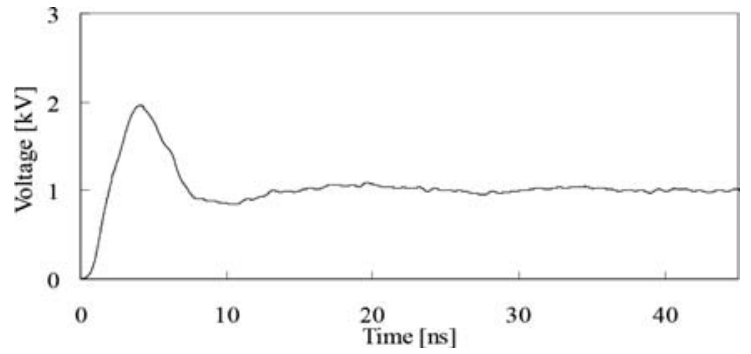

図 3 パルス電圧発生器の出力電圧測定波形

Fig. 3. Measured waveform of output voltage of the employed pulse voltage generator.

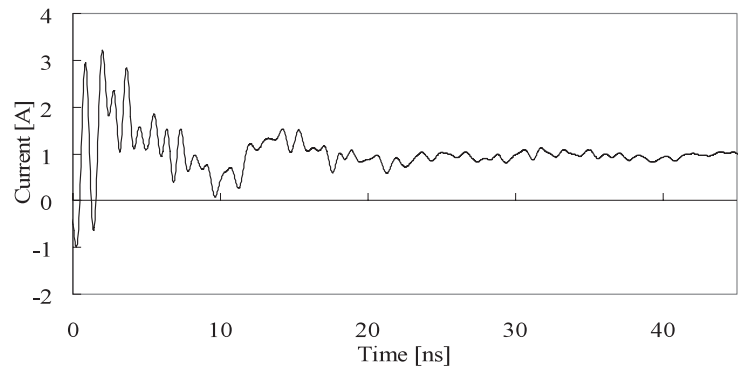

図 4 垂直銅線に流入する電流測定波形

Fig. 4. Measured waveform of current flowing in the vertical wire.

約 $1 \mathrm{~ns}$ の振動が観測されるが，これは CT とオシロスコー プをつなぐケーブルに誘導されたノイズと考えられる。

図 5(a), (b), (c), (d) に長さ $4 \mathrm{~m}$ の垂直な被覆銅線と垂直 導体プローブまでの距離が $D=1,2,3,4 \mathrm{~m}$ の場合の水平 電界の測定波形を示す。電界測定波形にも，図 4 の電流測 定波形とほほ同周期の高周波振動が観測される。この振動 は，擬似差動測定に用いた電圧プローブとオシロスコープ をつなぐケーブルに誘導されたノイズが完全には除去でき なかったことが原因と考えられる。な扔，電流波形に重畳 した高周波ノイズは時間の経過とともに減衰しているのに 対し, 電界波形に重畳した高周波ノイズは観測時間範囲に おいてほとんど減衰していないことから，電流測定波形の 高周波振動と電界測定波形の高周波振動との関係は低いと 考えられる。高周波ノイズを含んだと考えられる図 5 の測 
定波形から直接読み取った水平電界のピーク值は, $D=1$, 2,3 および $4 \mathrm{~m}$ で $E_{h}=24,12,7$ および $6 \mathrm{~V} / \mathrm{m}$ となって おり，距離にほぼ反比例している。なお，別の日（2005 年 10 月 25 日）にも同様の実験を実施したが，ほぼ同様の測定 波形が得られた。そのときの大地導電率は $\sigma=28.7 \mathrm{mS} / \mathrm{m}$

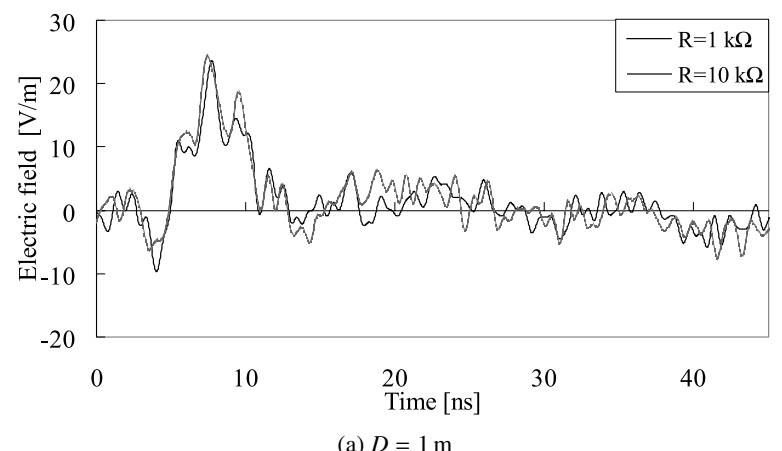

(a) $D=1 \mathrm{~m}$
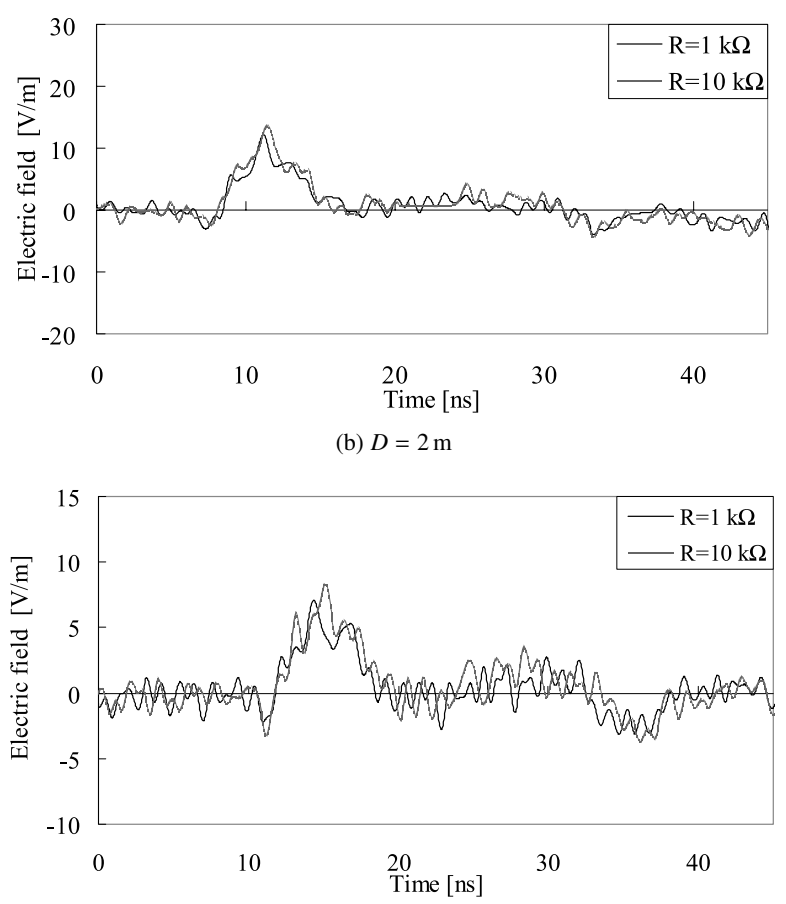

(c) $D=3 \mathrm{~m}$

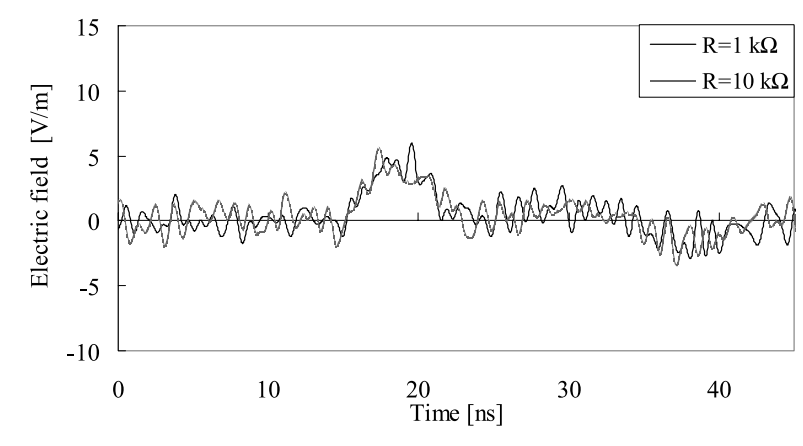

(d) $D=4 \mathrm{~m}$

図 5 簡易測定システムによる水平電界の測定波形

Fig. 5. Waveforms of horizontal electric field at different distances from the vertical copper wire for $R=1$ and $10 \mathrm{k} \Omega$ measured using the simple system.
であった。

\section{FDTD 計算}

〈4・1〉計算モデルＦDTD 計算モデルを図 6 に示す。 長さ約 $16 \mathrm{~m}$ の被覆銅線は, 被覆部分を無視し細線導体近似 表現法 ${ }^{(8)}$ を用いて半径 $0.5 \mathrm{~mm}$ の完全導体で模擬した。弛 んだ部分は階段近似により表現した。パルス電圧源は，半 径 $0.5 \mathrm{~mm}$ の垂直導体下端と大地の間に挿入した。この電 圧源は, 図 3 に示すパルス電圧発生器の出力電圧波形を出 力するように設定した。大地導電率は Wenner の 4 電極法 により測定して得た $\sigma=26.5 \mathrm{mS} / \mathrm{m}$ と設定した。大地比誘 電率の測定は行っていないが， $\varepsilon_{r}=10$ または 20 と設定し た。大地比透磁率は $\mu_{r}=1$ と設定した。水平電界評価用の 垂直導体プローブは埋設細線導体近似表現法 ${ }^{(9)}$ を用いて半 径 $6.5 \mathrm{~mm}$, 長さ $0.5 \mathrm{~m}$ の完全導体で模擬した。 $18 \times 5 \times 6 \mathrm{~m}^{3}$ $(360 \times 100 \times 120$ セル $)$ の直方体解析領域を確保し，この空 間を一辺 $50 \mathrm{~mm}$ の立方体セルに分割した。この直方体領域 を囲む 6 面には Liaoの 2 次吸収境界条件 (10) を適用した。

一般に, 大地導電率は周波数依存性を有するため, Wenner

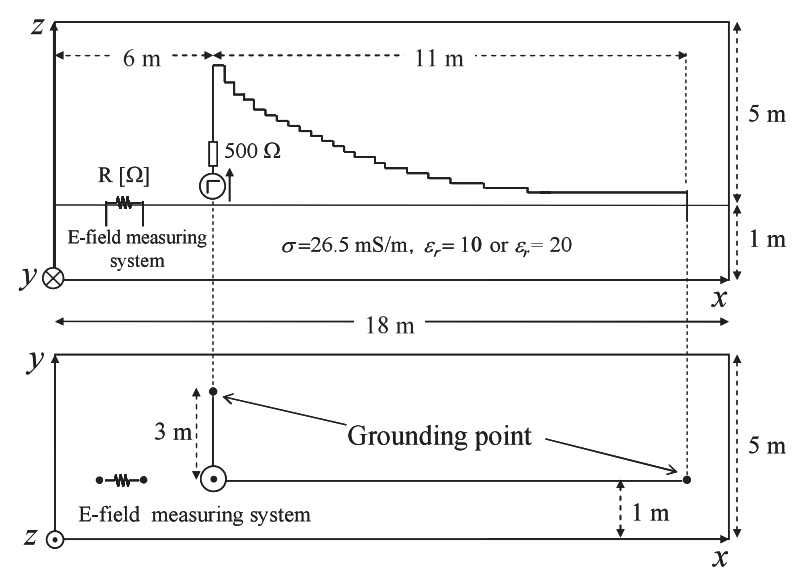

図 6 水平電界測定実験（図 2）の FDTD 計算モデル

Fig. 6. Side and plane views of an FDTD calculation model simulating the small-scale experiment for the measurement of horizontal electric field shown in Fig. 2.

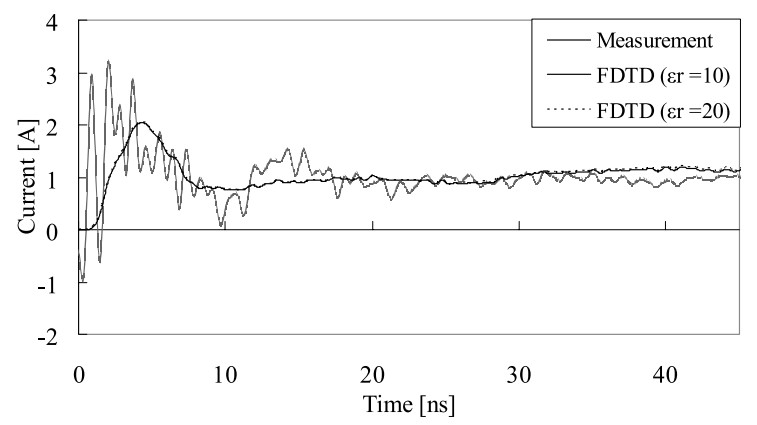

図 7 垂直銅線に流入する電流測定および計算波形

Fig. 7. Measured and calculated waveforms of current flowing in the vertical copper wire. 


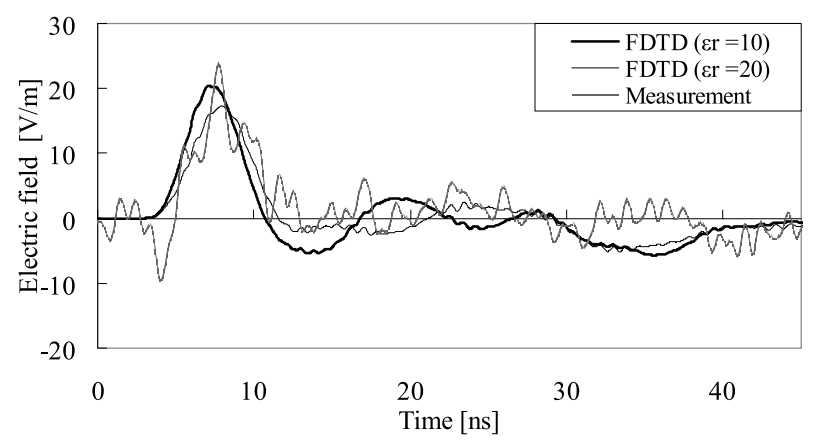

(a) $D=1 \mathrm{~m}$

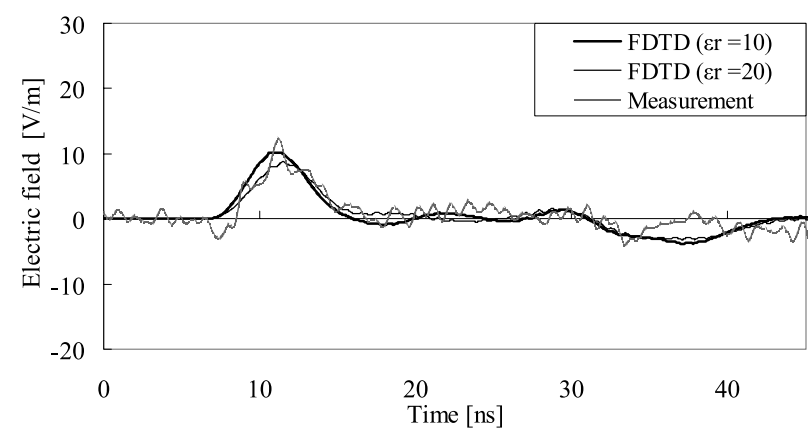

(b) $D=2 \mathrm{~m}$

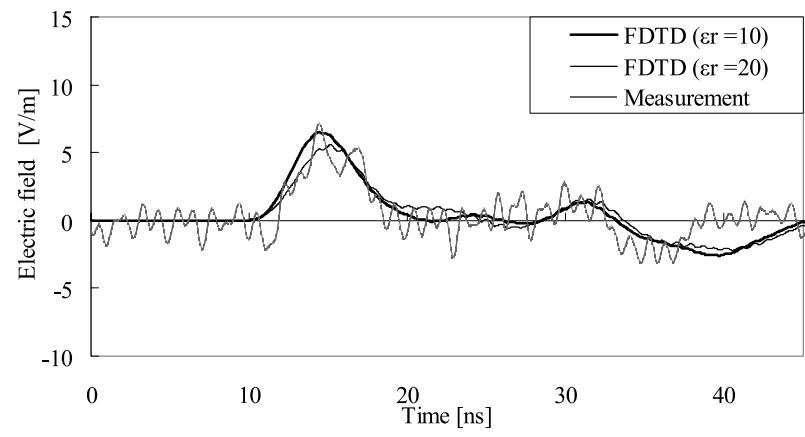

(c) $D=3 \mathrm{~m}$

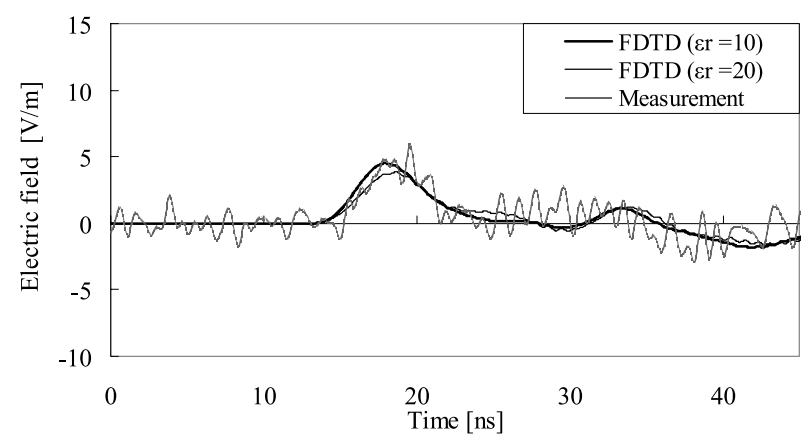

(d) $D=4 \mathrm{~m}$

図 8 簡易測定システムによる水平電界の測定波形と 計算波形 $(R=1 \mathrm{k} \Omega)$

Fig. 8. Measured and calculated waveforms of horizontal electric field at different distances from the vertical copper wire in the case of $R=1 \mathrm{k} \Omega$.

法で用いられる数十 $\mathrm{Hz}$ と雷電磁界パルスの周波数領域での 導電率の值は異なることが知られている。例えば，文献 (5) では，同じ大地の導電率が周波数 $40 \mathrm{~Hz}$ では $0.8 \mathrm{mS} / \mathrm{m}$ で あるのに対し，雷電磁界パルスの周波数領域では約半分の

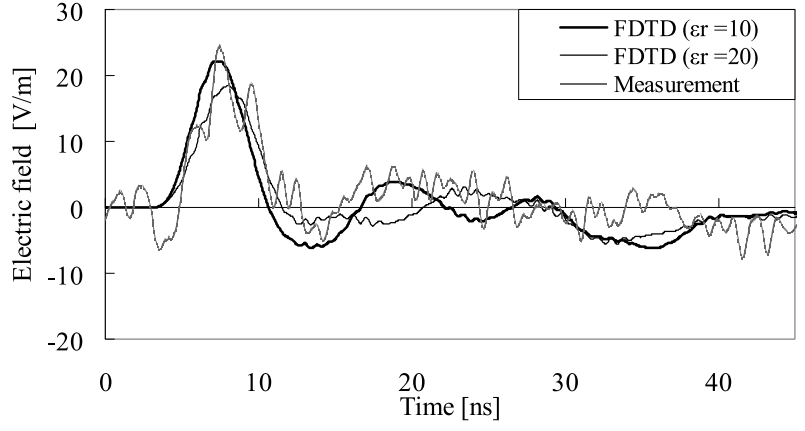

(a) $D=1 \mathrm{~m}$

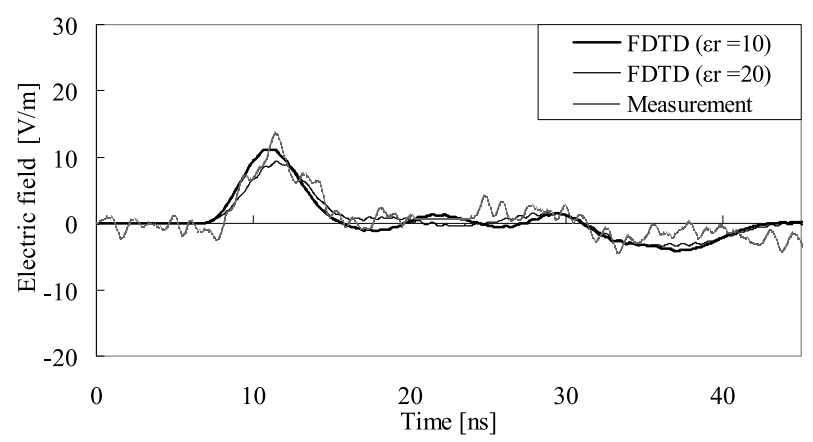

(b) $D=2 \mathrm{~m}$

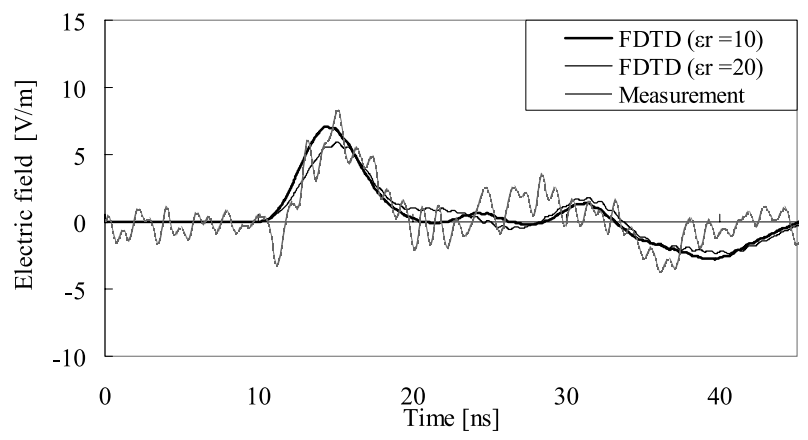

(c) $D=3 \mathrm{~m}$

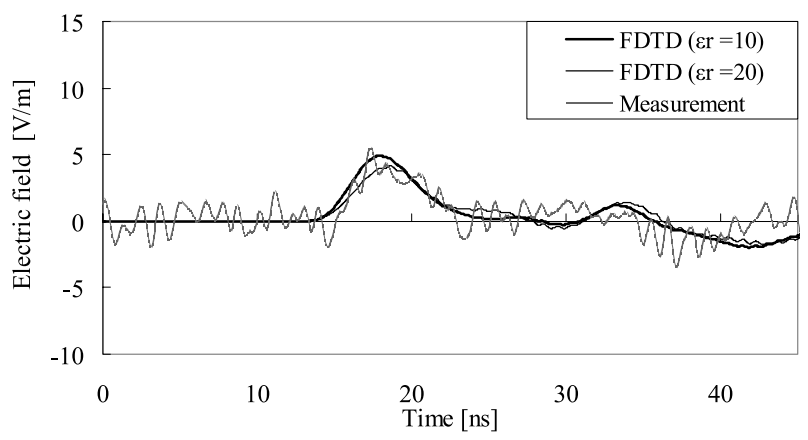

(d) $D=4 \mathrm{~m}$

図 9 簡易測定システムによる水平電界の測定波形と 計算波形 $(R=10 \mathrm{k} \Omega)$

Fig. 9. Measured and calculated waveforms of horizontal electric field at different distances from the vertical copper wire in the case of $R=10 \mathrm{k} \Omega$.

$0.39 \mathrm{mS} / \mathrm{m}$ になることが示されている。本研究では, 高周 波領域での大地導電率の測定や評価を行えなかったため, Wenner 法により測定した大地導電率 $\sigma=26.5 \mathrm{mS} / \mathrm{m}$ を FDTD 計算で用いた。高周波領域 $(f=1 / 10 \mathrm{~ns}=100 \mathrm{MHz})$ 
表 1 水平電界ピーク值の測定結果と計算結果

Table 1. Measured and calculated peak values of horizontal electric field.

\begin{tabular}{c|c|c|c|c}
\hline $\begin{array}{c}D \\
{[\mathrm{~m}]}\end{array}$ & $\begin{array}{c}R \\
{[\mathrm{k} \Omega]}\end{array}$ & $\begin{array}{c}\text { Measurement } \\
{[\mathrm{V} / \mathrm{m}]}\end{array}$ & $\begin{array}{c}\text { FDTD } \\
{[\mathrm{V} / \mathrm{m}]}\end{array}$ & $\begin{array}{c}\text { Difference } \\
{[\%]}\end{array}$ \\
\hline \multirow{2}{*}{1} & 1 & 24 & 20 & 16 \\
\cline { 2 - 5 } & 10 & 24 & 22 & 10 \\
\hline \multirow{2}{*}{2} & 1 & 12 & 10 & 19 \\
\cline { 2 - 5 } & 10 & 14 & 11 & 22 \\
\hline \multirow{2}{*}{3} & 1 & 7.1 & 6.5 & 9 \\
\cline { 2 - 5 } & 10 & 8.3 & 7.1 & 18 \\
\hline \multirow{2}{*}{4} & 1 & 6.0 & 4.5 & 32 \\
\cline { 2 - 5 } & 10 & 5.5 & 4.9 & 13 \\
\hline
\end{tabular}

での大地導電率が，この $1 / 2$ 倍あるいは 2 倍であるとき， 水平電界 $E_{h}$ は, $E_{h}$ と垂直電界 $E_{v}$ の比を表す wave tilt 式(11) $\left[E_{h}(\omega) / E_{v}(\omega)=1 /\left(\varepsilon_{r}+\sigma / j \omega \varepsilon_{0}\right)^{1 / 2}\right]$ によれば, $\sigma=$ $26.5 \mathrm{mS} / \mathrm{m}$ の場合の 1.1 倍および 0.80 倍となり，10 から $20 \%$ 程度の相違が生じることになる。

$\langle\mathbf{4} \cdot 2\rangle$ 計算結果 図 7 に長さ $4 \mathrm{~m}$ の垂直導体の下端 で流入する電流の FDTD 計算波形と実測波形（図 4 と同 じ）を示す。図 7 の測定電流波形には，〈3·2〉節で述べた 高周波ノイズが重畳しており，対応する FDTD 計算波形と の間に隔たりが見られる。しかし，図 3 に示したパルス電 圧発生器の印加電圧測定波形を, FDTD 計算での電圧源の 出力波形として使用しているため, 実験時に垂直導体に実 際に流入した電流波形はFDTD 計算波形に近いと考えられ る。図 8 に $R=1 \mathrm{k} \Omega$ の場合の水平電界の FDTD 計算波形 と実測波形（図 5 と同じ）を，図 9 に $R=10 \mathrm{k} \Omega$ の場合の 水平電界の FDTD 計算波形と実測波形を示す。 $R=1$ およ び $10 \mathrm{k} \Omega$ の両ケースおよび $\varepsilon_{r}=10$ および 20 の両ケースに おいて，FDTD 計算波形は実測波形に比較的良好に一致し ている。表 1 に水平電界測定波形のピーク值と FDTD 計算 波形のピーク値を示す。測定值と計算值の差はほぼ20\%以 内となっている。

$\langle\mathbf{4} \cdot \mathbf{3}\rangle$ 検 討 〈4·2〉節での簡易測定システムによ る水平電界の測定波形と FDTD 計算波形が比較的良好に一 致することが示されたが，同測定システムにより評価した水 平電界が真の水平電界に一致することが示されたわけでは ない。このため，測定システムを除去した場合の水平電界 を FDTD 法により直接計算し，それと測定システムをモデ ルに組み入れて評価したFDTD 計算結果との比較を行う。

図 10 にFDTD 法により直接計算した水平電界波形と垂 直導体プローブをモデルに組み入れて評価した水平電界の FDTD 計算波形を示す。また，このようにして計算した水 平電界のピーク值と垂直導体プローブをモデルに組み入れ て評価した水平電界のピーク值を表 2 に示す。計算波形お よびピーク值は良好に一致しており，簡易測定システムが 過渡水平電界の評価に有効であることが確認される。

これまでの計算では, 大地導電率が $\sigma=26.5 \mathrm{mS} / \mathrm{m}$ の

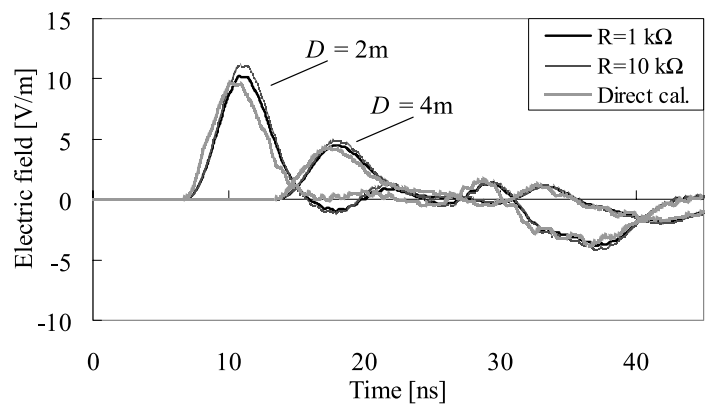

図 10 FDTD 法により直接計算した水平電界 波形と簡易測定システムを組み入れて 評価した水平電界波形

Fig. 10. FDTD-calculated waveforms of horizontal electric field for the configuration shown in Fig. 6 both in the presence of the simple measuring system and in its absence.

表 2 FDTD 法により直接計算した水平電界 ピーク值と簡易測定システムにより評価した 水平電界ピーク值

Table 2. Peak values of FDTD-calculated horizontal electric field for the configuration shown in Fig. 6 both in the presence of the simple measuring system and in its absence.

\begin{tabular}{c|r|c|c|c}
\hline $\begin{array}{c}D \\
{[\mathrm{~m}]}\end{array}$ & $\begin{array}{c}R \\
{[\mathrm{k} \Omega]}\end{array}$ & $\begin{array}{c}\text { Direct cal. } \\
{[\mathrm{V} / \mathrm{m}]}\end{array}$ & $\begin{array}{c}\text { Measuring system } \\
{[\mathrm{V} / \mathrm{m}]}\end{array}$ & $\begin{array}{c}\text { Difference } \\
{[\%]}\end{array}$ \\
\hline \multirow{2}{*}{1} & 1 & \multirow{2}{*}{20} & 20 & 5 \\
\cline { 2 - 3 } & 10 & & 22 & 14 \\
\hline \multirow{2}{*}{2} & 1 & \multirow{2}{*}{9.7} & 10 & 5 \\
\cline { 2 - 3 } \cline { 4 - 5 } & 10 & & 11 & 14 \\
\hline \multirow{2}{*}{3} & 1 & \multirow{2}{*}{6.1} & 6.5 & 7 \\
\cline { 2 - 4 } & 10 & & 7.1 & 16 \\
\hline \multirow{2}{*}{4} & 1 & \multirow{2}{*}{4.3} & 4.5 & 5 \\
\cline { 2 - 4 } & 10 & & 4.9 & 14 \\
\hline
\end{tabular}

場合のみを対象に解析を行ったが, 以下では大地導電率を $\sigma=0.1 \mathrm{mS} / \mathrm{m}$ から $100 \mathrm{mS} / \mathrm{m}$ の範囲内で変化させた場合 の計算を行い, 適切な垂直導体プローブ間の挿入抵抗值に ついて検討を行う。表 3 に直接計算した水平電界のピーク 值と垂直導体プローブをモデルに組み入れて評価した水平 電界のピーク值の差の大地導電率依存性を示す。これは, $D=2 \mathrm{~m}$ の場合の計算結果であるが, $D=4 \mathrm{~m}$ の場合にも, 傾向はほぼ表 3 と同じである。これにより，挿入する抵抗 值は $1 \mathrm{k} \Omega$ 程度が適切であることが明らかである。

この測定システムでは, 埋設した長さ $0.5 \mathrm{~m}$ の垂直導体プ ローブ部分に垂直電界による誘導電流が生じる。垂直導体 プローブ頂部間をつなぐ抵抗が無いかあるいはその值が極 めて高く, かつ大地導電率が低い場合には, この誘導電流が 各々の垂直導体プローブ上を往復反射し, 測定波形を乱す。 FDTD 計算によれば，この影響は電界波形のピーク後に顕 著に現れ, 長さ $0.5 \mathrm{~m}$ の垂直導体プローブ上での進行波の 
表 3 FDTD 法により直接計算した水平電界 ピーク值と簡易測定システムにより評価した ピーク值の大地導電率依存性

Table 3. Dependences on ground conductivity of peak values of FDTD-calculated horizontal electric field for the configuration shown in Fig. 6 both in the presence of the simple measuring system and in its absence.

\begin{tabular}{c|r|c|c|c}
\hline $\begin{array}{c}\sigma \\
{[\mathrm{mS} / \mathrm{m}]}\end{array}$ & $\begin{array}{c}R \\
{[\mathrm{k} \Omega]}\end{array}$ & $\begin{array}{c}\text { Direct cal. } \\
{[\mathrm{V} / \mathrm{m}]}\end{array}$ & $\begin{array}{c}\text { Measuring system } \\
{[\mathrm{V} / \mathrm{m}]}\end{array}$ & $\begin{array}{c}\text { Difference } \\
{[\%]}\end{array}$ \\
\hline \multirow{2}{*}{0.1} & 1 & \multirow{2}{*}{11} & 12 & 1 \\
\cline { 2 - 3 } & 10 & & 13 & 11 \\
\hline \multirow{2}{*}{1} & 1 & \multirow{2}{*}{11} & 12 & 2 \\
\cline { 2 - 3 } \cline { 4 - 5 } & 10 & & 13 & 12 \\
\hline \multirow{2}{*}{10} & 1 & \multirow{2}{*}{11} & 11 & 4 \\
\cline { 2 - 3 } & 10 & & 12 & 14 \\
\hline \multirow{2}{*}{100} & 1 & \multirow{2}{*}{7.1} & 8.4 & 18 \\
\cline { 2 - 3 } & 10 & & 9.0 & 27 \\
\hline
\end{tabular}

往復伝搬時間に相当する周期約 $10 \mathrm{~ns}\left(=0.5 \mathrm{~m} \times 2 \times \varepsilon_{r}^{1 / 2} / c\right)$ の緩やかな振動が重畳する形で現れる。この誘導電流を減 衰させるためには, 垂直導体プローブのサージインピーダ ンスの值と桁が違わない程度の抵抗で頂部間をつなぐ必要 がある。抵抗值が低い $1 \mathrm{k} \Omega$ を用いた場合の方が，電界ピー ク值の誤差が小さいのも，この特性が関係していると考え られる。

なお，実際の帰還雷撃に伴って生じる垂直電界と水平電

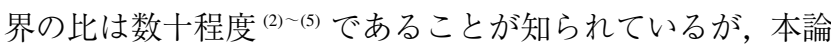
文で採用した図 2 あるいは図 6 の配置では長さ約 $11 \mathrm{~m}$ の 斜めの電流路が存在するため, 垂直電界と水平電界の比は 5 倍程度であった。

\section{5. 結言}

本論文では, 帰還雷撃によって大地表面に発生する過渡水 平電界の簡易測定システムの動作特性について検討を行っ た。この測定システムは, 長さ $0.5 \mathrm{~m}$, 間隔 $0.25 \mathrm{~m}$ の垂直

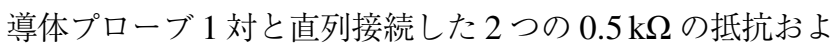
び差動測定用の電圧プローブ 1 対から構成される。同測定 システムにより, 導電率 $\sigma=0.1 \sim 100 \mathrm{mS} / \mathrm{m}$ の大地表面上 の水平電界を $20 \%$ 程度の誤差で測定可能であることを縮小 モデル実験およびFDTD シミュレーションにより示した。

(平成 18 年 2 月 20 日受付, 平成 18 年 6 月 2 日再受付)

\section{文献}

（1）例えば, Y.T. Lin, M.A. Uman, J.A. Tiller, R.D. Brantley, E.P. Krider, and C.D. Weidman: "Characterization of lightning return stroke electric and magnetic fields from simultaneous two-station measurements", J. Geophys. Res., Vol.84, pp.6307-6314 (1979)

(2) E.M. Thomson, P.J. Medelius, M. Rubinstein, M.A. Uman, J. Johnson, and J.W. Stone: "Horizontal electric fields from lightning return strokes", $J$. Geophys. Res., Vol.93, No.D3, pp.2429-2442 (1988)
(3) K. Michishita: "Analysis of voltages induced on an overhead distribution line and their digital measurement", Ph.D. thesis, University of Tokyo (1990) (in Japanese)

道下幸志：「配電線誘導雷電圧の解析とディジタル計測」, 東京大学 学位論文 (1990)

(4) K. Michishita, M. Ishii, J. Hojo, M. Komatsubara, T. Kawamura, S. Oguma, and Y. Hongo: "Horizontal electric field waveform associated with cloudto-ground stroke", T. IEE Japan, Vol.110-B, No.11, pp.986-987 (1990-11) (in Japanese)

道下幸志·石井 勝·北條準一 - 小松原実·河村達雄 - 小熊修二郎·本 郷保二：「対地雷撃に伴う水平電界波形」, 電学論 B, 110, 11, pp.986-987 (1990-11)

(5) K. Michishita, M. Ishii, and J. Hojo: "Measurement of horizontal electric fields associated with distant cloud-to-ground strokes", J. Geophys. Res., Vol.101, No.D2, pp.3861-3867 (1996)

(6) K. Sao, M. Takagi, and H. Jindo: "Remarks on the Erdantenna", J. IECE, Vol.46, No.12, pp.1870-1871 (1963-12) (in Japanese)

佐尾和夫 ·高木増美・神藤英彦 :「エルドアンテンナについての考 察」, 信学誌, 46, 12, pp.1870-1871 (1963-12)

(7) K.S. Yee: "Numerical solution of initial boundary value problems involving Maxwell's equations in isotropic media", IEEE Trans. Antennas Propagat., Vol.14, No.4, pp.302-307 (1966)

(8) T. Noda and S. Yokoyama: "Thin wire representation in finite difference time domain surge simulation”, IEEE Trans. Power Delivery, Vol.17, No.3, pp.840-847 (2002)

(9) Y. Baba, N. Nagaoka, and A. Ametani: "Modeling of thin wires in lossy medium for FDTD simulations", IEEE Trans. Electromag. Compatibility, Vol.47, No.1, pp.54-60 (2005)

(10) Z.P. Liao, H.L. Wong, B.-P. Yang, and Y.-F. Yuan: "A transmitting boundary for transient wave analysis", Science Sinica, Series A, Vol.27, No.10, pp.1063-1076 (1984)

(11) J. Zenneck: Wireless Telegraphy, McGraw-Hill, New York (1915)

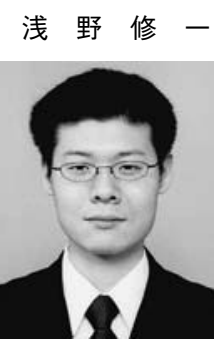

(学生員) 1980 年 5 月生。 2004 年 3 月同志社大 学工学部電子工学科卒業。同年 4 月同大学大学院 工学研究科電気工学専攻博士課程 (前期) 進学。 現在に至る。

馬 場 吉 弘 (正員) 1971 年 2 月生。 1994 年 3 月東京大学工

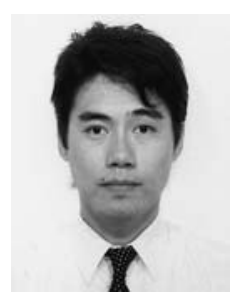
学部電気工学科卒業。1999 年 3 月同大学大学院工 学系研究科電気工学専攻博士課程修了。博士（工 学)。同年 4 月同志社大学助手, 2001 年 4 月同専 任講師。2005 年 4 月同助教授, 現在に至る。2003 年 4 月から 2004 年 8 月フロリダ大学客員研究員。 電磁界パルスに関する研究に従事。1999 年電気 学会論文賞。2002 年, 2004 年同発表賞。AGU,

IEE および IEEE 会員。

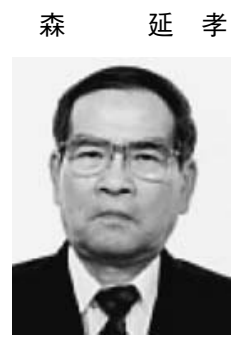

（正員） 1943 年 10 月生。1966 年 3 月同志社大 学電気工学科卒業。同年 4 月同大学助手。1993 年同実験講師, 現在に至る。主として, サージ現 象の測定, 絶縁ガスおよび絶縁材料の放電現象の 研究に従事。 
長 岡 直人 (正員) 1957 年 10 月 21 日生。1 982 年 3 月同志

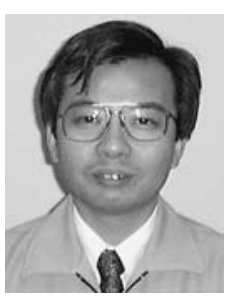
社大学大学院工学研究科博士前期課程修了。1985 年同大学工学部助手, 1988 年同専任講師, 1992 年同助教授。1 999 年同教授, 現在に至る。2005 年 10 月から 2006 年 9 月アイルランド国立大学 ゴールウェイ校客員教授。博士 (工学)。電気回 路シミュレーションおよび数值解析モデルの開発 に従事。1993 年電気設備学会論文賞，1994 年照 明学会論文賞。電気設備学会, 照明学会, IEE および IEEE 会員。
雨 谷 昭 弘（正員） 1944 年 2 月生。1968 年 3 月同志社大 学大学院電気工学専攻修士課程修了。1973 年又 ンチェスタ大学院博士課程修了。Ph.D. 1977 年同 志社大学助教授。1976 年から 1981 年米国 BPA にて EMTP の開発に従事。1985 年同志社大学教 授，現在に至る。1988 年 Leuven 大学教授兼任。 1966 年から 1998 年同志社大学理工学研究所所長。 1998 年から 2001 年同大学学術情報センター所長。 2005 年から学校法人同志社評議員。2003 年電気学会理事, 2004 年 同副会長。分布定数回路, 過渡現象, 高調波, 数值解析法の開発に従 事。1976 年電気学会論文賞。1996 年照明学会論文賞。英国技術士。 CIGRE 特別会員。IEE および IEEE フェロー。 